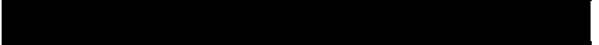

\title{
Kajian Transformasi Struktural dan Dampaknya dalam Perekonomian Batam
}

\author{
Oleh Edy Suandi Hamid
}

\begin{tabular}{|l|l|}
\hline & $\begin{array}{l}\text { Edy Suandi Hamid, adalah dosen negeri yang dipekerjakan } \\
\text { pada Fakultas Ekonomi Universitas Islam Indonesia disamping } \\
\text { juga sebagai staf peneliti pada Pusat Penelitian Pembangunan } \\
\text { Pedesaan dan Kawasan (P3PK) UGM (s/d 1994) dan } \\
\text { Sekretaris Ikatan sarjana ekonomi Indonesia DIY. Lahir di: } \\
\text { Tanjung Enim, 11 Desember 1957, dan menyelesaikan studi } \\
\text { pembangunan (Umum), April 1983 S1 serta S2 dari Faculty } \\
\text { of Economics Thammasat University, Bangkok 1990. }\end{array}$ \\
Pernah menjadi wartawan dan redaksi ekonomi harian Kedaulatan rakyat, serta \\
Pimpinan Redaksi Majalah Equilibrium (FE UGM). Kini aktif dalam kegiatan penelitian \\
Konsumenyangkut masalah pedesaan. Menulis buku Pengantar Teori Perilaku \\
Indonesia (bersama Drs. Effendy Ari, 1985), menyunting buku Kredit Pedesaan di \\
(bersma Prof. Mubyarto, 1987)
\end{tabular}

\section{Latar Belakang}

Jika dilihat dari sisi historis pengenbangan kawasan Batam, tidak bisa dilepaskan dari posisi geografis pulau ini, yang dilihat dari sudut pandang ekonomi sangat strategis. Pulau Batam terletak pada salah satu kawasan yang merupakan jalur lalulintas perdagangan terpadat di dunia, yang jaraknya hanya 20 km. (12,5 mil) dari Singapura. Namun demikian, posisi strategis tersebut sampai dengan akhir tahun 1960-an secara ekonomis belum sepenuhnya dimanfaatkan oleh pemerintah Indonesia. Pada waktu itu Batam dan pulaupulau kecil di sekitarnya masih termasuk daerah perbatasan yang tidak banyak mendapatkan perhatian secara khusus dari pemerintah, sebagaimana daerahdaerah pinggiran lainnya. Batam waktu itu hanyalah suatu daerah kecamatan yang masuk dalam wilayah Kabupaten Tingkat II Kepulauan Riau, dengan infrastruktur yang terbatas dan kepadatan penduduk yang sangat rendah.
Perubahan-perubahan mulai terjadi sejak awal tahun 1970-an, yang diawali dengan dikeluarkannya Keppres No. 65 tahun 1970, yakni tentang Proyek Pengembangan Pulau Batam. Pada awalnya tanggung jawab pengembangan Pulau Batam tersebut diserahkan kepada Pertamina, sesuai dengan kegiatan awalnya yang ditujukan untuk menunjang kegiatan pertanian dan pencarian minyak lepas pantai. Keppres ini diikuti dengan beberapa Keppres dan perangkat peraturan lainnya, yang pada prinsipnya memberikan suatu ketentuan dan perlakuan khusus dalam pemanfaatan Pulau Batam sebagai salah satu wilayah pusat pengembangan ekonomi nasional, khususnya yang berkaitan untuk menunjang pengembangan industri dan lalulintas perdagangan internasional.

Sejak itu berbagai sarana dan prasarana dibangun di Batam. Namun sejalan dengan fluktuasi ekonomi dunia dan nasional, maka pembangunan tersebut tidak selalu bérjalan lancar. Berbagai pembangunan tersebut 
pernah tersendat-sendat, bahkan mengalami stagnasi, terutama pada waktu Pertamina mengalami kesulitan keuangan pada pertengahan tahun 1970-an, yang kemudian diikuti dengan pengalihan tanggung jawab pengembangan Batam dari Pertamina kepada pemerintah. Oleh karena itu tidak mengherankan walaupun rintisan pengembangan Batam sudah dilakukan sejak tahun 1970, namun perkembangan yang pesat baru terjádi dalam akhir tahun 1980-an.

Walaupun mengalami pasang-surut, sejak dinyatakannya Batam sebagai daerah industri, perkembangan ekonomi di daerah ini sangat pesat dan tumbuh di atas rata-rata perkembangan ekonomi nasional. Berbagai sarana pendukung dibangun schingga banyak menarik para investor ke sana. Pada tahun 1978 pemerintah menetapkan semua kawasan Pulau Batam sebagai bonded area, dan pada tahun 1984 ditambah pulau-pulau Janda Barias, Tanjung Satu, Ngenang, Kasem dan Moi-moi sebagai bonded area. Kemudian pada tahun 1992 diperluas lagi meliputi Pulau Rempang, G.lang dan gugus pulau kecil di sekitamya.

Sebagai bonded zone, Pulau Batam berfungsi sebagai pengembangan industri, alihkapal (transhipment point), perdagangan bebas dan pariwisata. Fungsi ini lidak bisa dilepaskan dari adanya harapan dari Pulau Batam untuk mendapatkan spill over dari perkembangan yang pesat di negara tetangga Singapura, yang tclah berkcmbang menjadi negara industri baru. Dengan posisi yang demikian, Batam telah mengalami perkembangan ckonomi yang sangat pesat.

Jika dilihat dari indikator makro yang ada tampak banyak prestasi menggembirakan dalam proses perkembangan ekonomi di Batam. Namun demikian dari sisi mikro ternyata muncul pula beberapa dampak yang tidak begitu menggembirakan. Dalam proses pembangunan itu telah pula menampakkan suatu dualisme ekonomi dari kehidupan masyarakatnya, adanya fenomena pengangguran yang cenderung scmakin besar, penyediaan sarana publik yang semakin terbatas, munculnya pemukiman liar, dan sebagainya.

Dengan perkembangan kondisi ekonomi dunia yang sangat dinamis, maka perkembangan yang terjadi di Batam tampaknya memang masih sulit diperkirakan, khususnya dalam konteks untuk menjadikannya sebagai wilayah yang perkembangannya mengarah seperti Singapura. Bagaimanapun, perkembangan dan kondisi eksternal akan sangat besar -- lebih besar dari nasional - pengaruhnya atas perekonomian Batam, yang memiliki posisi sebagai bonded area ini. Oleh karena itu, menjadi sangat penting untuk mengkaji pola perkembangan ekonomi Batam ini, khususnya yang berkaitan dengan proses transformasi struktural yang telah terjadi, serta dampak yang ditimbulkan, dan berbagai masalah yang akan dihadapi pada masa yang akan datang yang berkaitan dengan perkembangan ekonomi umumnya.

\section{Pokok Masalah dan Tujuan Penelitian}

Penelitian ini akan membatasi masalah terutama pada aspek perkembangan ekonomi secara makro dan kajian spesifik atas proses perubahan struktural dari perekonomian Batam, serta penganuhnya dalam aspek yang berkaitan dengan distribusi pendapatan masyarakat. Tekanan kajian adalah pada wilayah yang berada dalam otoritas OPDIPB (Otorita Pengembangan Daerah Industri Pulau Batam). Dengan demikian daerah-daerah Kodya Batam di luar OPDIPB tidak akan mendapat perhatian pengkajian secara khusus.

Penelitian ini dimaksudkan untuk mengkaji perkembangan ekonomi Batam secara sektoral dengan melihat aspek transformasi struktural yang terjadi dalam komposisi pada Produk Domestik Regional Bruto-nya. Kemudian diteliti pula proses transformasi struktural dalam kaitan.dengan sumbangan sektoral dalam komposisi ketenaga kerjaan.

Aspek lain yang diteliti adalah berkaitan dengan dampak transformasi struktural di atas terhadap pola distribusi pendapatan masyarakat yang ada di Batam, serta melihat prospck perkembangan ekonomi Batam secara kescluruhan, serta permasalahan-permasalahan sosial-ekonomi yang muncul, termasuk aspek ketenagakcrjaan.

\section{Metode Analisis}

Mctode analisis dalam penelitian ini terutama bersifat descriptive analysis yang berdasarkan pada data primer dan sekunder yang dikumpulkan dari berbagai sumber. Untuk mendukung kajian yang dimaksud, maka digunakan pula analisis tabulatif dengan mengkaitkannya dengan aspek mikro dan aspek makro yang berhubungan dengan lingkungan ekonomi (economic environment) nasional dan intemasional sehingga dapat menjelaskan aspek perubahan yang ada serta kecenderungan yang diperkirakan akan terjadi pada masa yang akan datang.

Scbagaimana tujuan penelitian, variabel-variabel yang menjadi tekanan dalam penelitian ini adalah menyangkut aspek ekonomi makro secara agresif, serta secara sektoral berdasarkan bidang usahanya.

\section{Temuan/Hasil Penelitian .}

Dari hasil penelitian yang telah dilakukan ada beberapa hal yang dapat dikemukakan dan disimpulkan yang berkaitan dengan perkembangan di Kodya Batam umumnya dan wilayah Batam yang berada di bawah OPDIPB khususnya, terutama yang berkaitan dengan proses transformasi ekonomi dan prospeknya, serta 
dampak sosial ekonomi yang muncul.

Pertama, secara makro pembangunan di Pulau Batam telah menunjukkan hasil yang menggembirakan. Bahkan pembangunan Pulau Batam dapat dijadikan sebagai salah satu model pembangunan yang dapat memacu penanaman modal asing maupun domestik, meningkatkan peluang kerja dan berusaha serta mendorong laju pertumbuhan ekonomi serta disertai dengan transformasi struktural dengan pesat. Transformasi struktural di Batam, jika dilihat dari perkembangan atas PDB-nya, yang sangat cepat tersebut sangat berbeda dengan bagian bawah wilayah Indonesia lainnya. Hal demikian dapat terjadi karena adanya akselerasi yang cepat dari pembangunan industri itu sendiri, sejalan dengan arah strategi pengembangan Pulau Batam, dan juga karena adanya kerja sama dengan negara tetangga Singapura yang mengarahkan sebagian pengembangan industrinya ke Pulau Batam tersebut. Kemajuan pembangunan Pulau batam terscbut tidak saja memberikan koniribusi pada pembangunan ekonomi nasional, melainkan juga pembangunan daerah, baik pembangunan di Pulau Batam itu sendiri maupun pembangunan Propinsi Riau pada umumnya.

Tabel 3.1: Pcrtumbuhan Ekonomi Rata-rala per tiahun (1983-1993)

\begin{tabular}{lrrrr}
\hline Scklor & $1983-1989$ & Pelita IV & Pclita V & 1993 \\
\hline Pertanian & 12.98 & 14,43 & 23,28 & 4.68 \\
Pertambangan & 7,50 & 9.17 & -17.51 & 5.02 \\
Industri & 9,04 & 7.63 & 26.88 & 23,31 \\
Listrik,gas,air & 17,06 & 21.78 & 33.17 & 11,67 \\
Konstruksi & 6,58 & 5.05 & 11.34 & 10.00 \\
Perdag/hotel/rest. & 6.65 & 7.94 & 11.60 & 14.06 \\
Perhubungan & 6,96 & 6,65 & 10.49 & 7,70 \\
Bank/lbg. keuangan 16,06 & 9.74 & 33.82 & 20.18 \\
Sewa rumah & 5,84 & 4.83 & 28,60 & 9,68 \\
Pemerintahan/pert. & 4,10 & 4.91 & 4.91 & 4,41 \\
Jasa-jasa lain & 9.15 & 10,28 & 10.91 & 11,48 \\
& & & & \\
\hline Laju PDRB & 8.01 & 7.59 & 19.37 & 16.78 \\
\hline
\end{tabular}

Sumber: 1.Otorita Batam/Lemtek UI. Evaluasi Master Plan Pulau Balam (1992)

2.Bappeko Batam/Kantor Statistik-BPS Batam, Perkiraan Pendapalan Regional Kotamadya Batam (1994)

Jika dilihat dari perkembangan pertumbuhan ekonomi di Batam ini, tampak secara nyata suatu perkembangan yang pesat terjadi setelah Pelita $\mathrm{V}$.
Namun ini tidak berarti pada Pelita sebelumnya pertumbuhan ekonominya rendah. Pertumbuhan ekonomi pada Pelita sebelumnya, seperti pada Pelita III dan IV sudah cukup tinggi, sedikit di atas rata-rata pertumbuhan ekonomi nasional. Namun demikian pertumbuhan yang sangat cepat terjadi pada Pelita V dan berlanjut pada awal Pelita VI.

Perkembangan yang pesat ini dapat terjadi karena adanya suatu strategi baru dalam pengembangan wilayah tersebut, dengan melibatkan negara tetangga Singapura, serta lingkungan ekonomi regional dan global yang semakin kondusif. Secara bilateral hubungan kerja sama ekonomi Indonesia-Singapura untuk mengembangkan wilayah Batam tersebut ditingkatkan sejak menjelang akhir tahun 1980-an. Singapura yang terus mengalami limpahan investasi dan mengalami kesulitan untuk perluasan industri yang ada, mulai memanfaatkan Batam sebagai wilayah yang dapat saling mendukung perkembangan ekonominya. Batam juga menjadi tempat relokasi bagi industri dari negara-negara seperti Jepang. yang melihat adanya keuntungan komparatif dari investasi di wilayah Batam tersebut dibandingkan dengan lokasi investasi sebelumnya. Adanya pertambahan dan ekspansi dari unit usaha industri yang lama serta derasnya investor baru yang masuk, yang kemudian berproduksi, telah memacu pertumbuhan ekonomi akhirakhir ini.

Dengan kondisi yang demikian, laju pertumbuhan Pulau Batam menjadi sangat pesat, dan lebih tinggi dibandingkan Propinsi Riau maupun wilayah Indonesia lainnya. Sebagai gambaran untuk tahun 1992 laju pertumbuhan ekonomi Batam (atas dasar harga konstan 1983) mencapai $17,13 \%$, sedangkan Riau dan Indonesia masing-masing hanya $9,37 \%$ dan $8,11 \%$. Bahkan untuk tahun 1991 angkanya jauh lebih tinggi lagi, yakni $31,28 \%$ untuk Batam dan hanya 10,53 dan 6,58\% untuk Propinsi Riau dan rata-rata pertumbuhan ekonomi Indonesia sccara keseluruhan.

Kedua, walaupun dari sisi makro proses transfortasi struktural di Batam telah menunjukkan prestasi yang baik, namun jika dilihat dari sudut mikro, model pembangunan Pulau Batam selama ini temyata telah menimbulkan berbagai impliḳasi yang tidak semuanya sejalan dengan perkembangan yang diharapkan. Adanya arus migrasi yang sangat deras telah menimbulkan berbagai masalah yang berkaitan dengan aspek kependudukan dan penyediaan lapangan kerja serta penyediaan sarana publik. Hal ini terjadi karena memang sampai saat ini belum ada mekanisme yang dapat secara tegas dan jelas yang dapat mengendalikan migrasi yang tidak sesuai dengan kebutuhan pembangunan di Batam tersebut. Masuknya tenaga kerja yang sangat banyak dan tidak sesuai dengan kualifikasi 
yang dibutuhkan tersebut telah berakibat pada meningkatnya angka pengangguran dan pengembangan sektor-sektor informal secara berlebihan serta masalahmasalah sosial lainnya, seperti munculnya pemukiman liar yang tidak sejalan dengan tataruang pengembangan Batam serta berkembangnya pelacuran baik yang dilakukan pekerja yang khusus berprofesi sebagai pelacur, maupun pekerja industri yang mencari tambahan pendapatan dengan menjadi pelacur tersebut.

Tabel 3.2: Kontribusi Sektoral atas PDRB Batam 1983-1993 (atas dasar harga Konstan 1983)

\begin{tabular}{lrrrrrr}
\hline Sektor & 1983 & 1986 & 1989 & 1991 & 1992 & 1993 \\
\hline & & & & & & \\
Pertanian & 0,63 & 0,71 & 0,82 & 1,18 & 1,04 & 0,93 \\
Pertambangan & 8,14 & 8,70 & 8,49 & 2,75 & 2,01 & 2,81 \\
Industri & 32,73 & 32,92 & 34,60 & 42,56 & 41,91 & 44,26 \\
Listrik,gas,air & 0,48 & 0,64 & 0,79 & 1,29 & 1,27 & 1,22 \\
Konstruksi & 2,04 & 2,18 & 1,88 & 1,66 & 1,51 & 1,42 \\
Perdag/hotel/rest. & 20,71 & 18,91 & 19,25 & 16,26 & 17,29 & 16,88 \\
Perhubungan & 17,44 & 17,88 & 16,46 & 14,86 & 13,10 & 12,08 \\
Bank/lbg. Keuangan & 5,01 & 6,30 & 7,32 & 11,54 & 11,24 & 11,57 \\
Sewa rumah & 4,70 & 4,39 & 4,15 & 5,43 & 5,96 & 5,60 \\
Pemerintahan/pert. & 7,04 & 6,33 & 5,68 & 4,14 & 3,77 & 3,37 \\
Jasa-jasa lain & 1,08 & 1,14 & 1,15 & 0,95 & 0,90 & 0,86 \\
\hline PDRB & 100 & 100 & 100 & 100 & 100 & 100 \\
\hline
\end{tabular}

Sumber: 1. Otorita Batam/Lemtek UI (1991)

2. Bappeko/BPS (1994)

3. Satlak Batam/Kantor Statistik Riäu (1994)

Ketiga, proses transformasi struktural yang mengarah kepada proses industrialisasi di Pulau Batam telah berjalan dengan cepat. Transformasi struktural yang terjadi merupakan transformasi yang berdimensi ganda, yakni dilihat dari struktur PDRB maupun dari struktur penyerapan tenaga kerja sektoralnya. Proses ini tidak saja menempatkan sektor industri sebagai sektor yang paling dominan dalam menghasilkan output regional Batam, melainkan juga sebagai sektor yang menyerap tenaga kerja terbesar. Proses seperti ini juga terjadi dalam proses industrialisasi di negara-negara industri, sehinigga merupakan pola atau jalur yang ditiru oleh negara-negara berkembang. Pola yang secara nasional baru secara parsial dicapai, yakni hanya pada aspek kontribusi PDB, namun temyata bisa diwujudkan secara menyeluruh dalam kasus pembangunan di Batam.
Tabel 3.3: Kontribusi Sektoral terhadap Penyerapan Tenaga Kerja 1994 (dan Indonesia \%)

\begin{tabular}{|c|c|c|c|c|c|}
\hline Sektor & Pria & Wanita & Jumlah & Persen. & $\left.(\mathrm{RI})^{*}\right)$ \\
\hline Pertanian & 1241 & 77 & $\cdot 1318$ & $-2,1$ & 46,22 \\
\hline Pertambangan & 261 & 40 & 301 & $=0,5$ & 0,94 \\
\hline Industri & 15586 & 23558 & 39144 & 62,8 & 13,26 \\
\hline Listrik,gas,air & 530 & - 21 & 551 & 0,9 & 0,22 \\
\hline Konstruksi & 11051 & 607 & 11658 & 18,7 & 4,34 \\
\hline Pengangkutan & 1719 & 222 & 1941 & 3,1 & 4,12 \\
\hline Perdagangan & 4289 & 901 & 5190 & 8,3 & 17,05 \\
\hline Keuangan,asuransi & 528 & 164 & $6 \dot{92}$ & 1,1 & 0,76 \\
\hline Jasa-jasa lain & 1332 & 231 & 1563 & 2,5 & 13,13 \\
\hline Jumlah & 36541 & 25817 & $62358^{\circ}$ & 100 & 100 \\
\hline
\end{tabular}

Kèterangan: *) Data untuk Indonesia keseluruhan (\%)

Sumber: Kantor Depnaker Batam 1994

Keempat, seimbangnya kontribusi sektoral terhadap PDRB dan penyerapan tenaga kerja ini tampaknya merupakan faktor yang menghasilkan data makro distribusi pendapatan di Batam tidak terlalu timpang atau masuk dalam kategori "ketidakmerataan lunak" (low inequality), yang tercermin dari Indeks Gininya yang lebih kecil dari angka Propinsi Riau maupun nasional. Pada tahun 1992 Gini Ratio Batam tersebut adalah 0,287 , sedangkan Riau adalah 0,333 dan Indonesia secara keseluruhan adalah 0,32 (1993). Ini dapat terjadi karena secara nasional maupun regional umumnya transformasi struktural di tanah air tidak secara cepat diikuti oleh penciptaan lapangan kerja di sektor industri, sehingga sektor pertanian tetap menjadi sektor yang dominan dalam menampung tambahan angkatan kerja baru yang masuk ke bursa tenaga kerja. Banyaknya pekerja di sektor pertanian, dan kecilnya penerimaan mereka, merupakan unsur yang memperbesar Gini Ratio di luar Batam tersebut.

Tabel 4.4: Distribusi Pendapatan Masyarakat di Batam, Riau dan Indonesia (persentase terhadap PDRB)

Kelompok Pendapatan

Daerah $\quad 40 \%$ Rendah $40 \%$ Sedang $20 \%$ Tinggi

\begin{tabular}{llll}
\hline Batam (1992) & 20,47 & 48,35 & 31,18 \\
Riau (1992). & 20,61 & 35,67 & 43,68 \\
Indonesia (1993) & 14,61 & 41,52 & 43,87 \\
\hline
\end{tabular}

Sumber: 1: Bappekỏ dan KS-BPS Batam (1993)

2. Ananta, Aris (1995) 
Tabel 4.5: Gini Ratio Batam, Riau dan Indonesia

\begin{tabular}{lr}
\hline Daerah & Gini Ratio \\
\hline Batam (1992) & 0,287 \\
Riau (1992) & 0,333 \\
Indonesia (1990) & 0,32 \\
\hline
\end{tabular}

Sumber :1. Bappeko dan KS-BPS Batam (1994)

2. Soemitro Djojohadikusumo (1991)

Kelima, perkembagan sektor industri yang ada di Batam saat ini terutama didukung oleh industriindustri skala besar yang padat teknologi. Investasi yang terjadi di sektor industri ini terutama didukung oleh sektor swasta, baik itu swasta domestik maupun asing.

Tabel 3.4: Investasi di Batam 1978 - 1994

(Ribuan dollar dan persen)

\begin{tabular}{lrrrrr}
\hline $\begin{array}{l}\text { Sumber } \\
\text { Investor }\end{array}$ & 1978 & 1983 & 1991 & 1993 & 1994 \\
\hline Pemerintah & 116.038 & 253.003 & 628.773 & 742.714 & 859.094 \\
& $(57,60 \%)$ & $(50,41 \%)$ & $(19,17 \%)$ & $(17,08 \%)$ & $(17,08 \%)$ \\
Swasta & 85.412 & 248.927 & 2653.018 & 3781.831 & 4169.208 \\
& $(42,40 \%)$ & $(49,59 \%)$ & $(80,93 \%)$ & $(83.58 \%)$ & $(82.92 \%)$ \\
\hline Total & 201.450 & 501.930 & 3280.791 & 4524.545 & 5028.302 \\
& $(100)$ & $(100)$ & $(100)$ & $(100)$ & $(100)$ \\
\hline
\end{tabular}

Sumber: 1. Kasatlak Batam (1995)

2. Lemtek UI (1992)

Industri-industri yang dibangun umumnya industri berskala besar yang menghasilkan semua komponen untuk produk akhimya sendiri. Jika dilihat kondisi yang ada sekarang, memang industri yang membutuhkan modal besar tersebut yang dominan di Batam. Misalnya, sampai dengan tahun 1994 jenis industri yang paling banyak adalah industri mesin, logam dasar dan elektronika yang meliputi 58 persen dari industri yang ada, diikuti aneka industri sebanyak 39,7 persen dan industri kimia 2,3 persen.

Arah pengembangan industri yang ditetapkan di Batam agaknya tidak bisa dilepaskan dari upaya agar subsektor yang dikembangkan tidak "bertabrakan" (substitute) dengan apa yang sudah dikembangkan di daerah lain, atau industri yang selama ini sudah menjadi unggulan ekspor Indonesia. Misalnya industri gament, merupakan industri yang tidak dianjurkan untuk dikembangkan di Batam. Namun demikian hal ini tampaknya tidak bisa diterapkan secara kaku, mengingat pemilik modal atau investor sekarang mempunyai banyak alternatif dalam melakukan investasinya di negara lain. Dengan demikian, industri yang sudah dihasilkan di daerah lain seyogyanya tetap dapat dikembangkan di Batam sepanjang industri itu juga berorientasi ekspor. Pada masa yang akan datang, persaingan untuk menarik investor ini akan semakin ketat, tidak saja antar negara melainkan antar daerah. Daya tarik Batam sebagai bonded zone, tidak selamanya menjadi keunggulan komparatifnya, karena kian terbukanya perekonomian dunia dan juga daerah lain di Indonesia. Oleh karena itu perlu dimunculkan dayatarik investasi lainnya, agar Batam bisa terus memanfaatkan peluang yang ada sejalan dengan perkembangan ekonomi yang sangat pesat di Asia Pasifik, dan kawasan sekitar Batam seperti Singapura-Johor-Riau. Untuk yang terakhir ini, Batam memiliki keunggulan karena lokasi yang strategis dan infrastruktur yang secara relatif sudah memadai.

Dalam rangka untuk lebih meningkatkan efisiensi dan sekaligụs juga kesempatan kerja, industri ini tampaknya perlu diarahkan pengembangan industri yang ada tidak hanya skala besar tetapi juga mendorong industri menengah yang dapat menjadi industri pemasok dari industri skala besar tersebut. Dengan demikian masing-masing industri dapat melakukan spesialisasi yang saling terkait dan saling mendukung, yang dapat mengarahkan proses produksi lebih efisien dan mengembangkan pelung berusaha dan bekerja di daerah ini.

Keenam, dalam kaitan pembangunan Batam sebagai daerah wisata, telah menunjukkan adanya tandatanda keberhasilan yang tercermin dari arus wisatawar asing dan penerimaan devisa yang meningkat dari kunjungan wisatawan ke Batam tersebut. Namun demikian kedatangan wisatawan tersebut belumlah dapat dikatakan optimal dan masih dapat terus ditingkatkan. Wisatawan ini terutama berasal dari negara tetangga Singapura, sementara wisatawan asing yang banyak datang ke Singapura belum dimanfaatkan pelung untuk mendatangkannya ke Indonesia. Ini terjadi karena masih kurangnya promosi serta obyek-obyek wisata yang dapat dikunjungi dan lebih menarik wisatawan tersebut.

Tabel 3.6: Perkembangan Wisatawan Asing ke Batam 1985 - 1994 (orang)

\begin{tabular}{lr}
\hline Tahun & Jumlah \\
\hline 1985 & 60.161 \\
1989 & 359.497 \\
1990 & 579.305 \\
1991 & 608.387 \\
1992 & 648.281 \\
1993 & 680.373 \\
1994 & 871.625 \\
\hline
\end{tabular}

Sumber : 1. OPDIPB (1994)

2. Kasatlak OPDIPB (1995) 
Dengan melihat posisi strategi Batam dan kemudahan pencapaiannya dari berbagai negara, maka prospek kepariwisataan Batam adalah cukup cerah. Sebagaimana diketahui, Singapura dan Malaysia telah menjadi bagian kecil dari negara-negara yang menjadi tujuan wisata yang semakin banyak digemari para wisatawan asing, yang sebagian di antaranya sebetulnya bisa dirangsang untuk juga meneruskan perjalanan ke Indonesia. Hal ini dapat dilakukan jika obyek wisata yang ditawarkan cukup banyak dan menarik. Namun kenyataannya sejauh ini jumlah obyek wisata tersebut relatif terbatas, karenanya masih sangat diperlukan penambahan daya tarik berupa berbagai obyek dan sarana rekreasi bagi wisatawan asing tersebut. Ini mengingat sumber devisa dari wisatawan asing tersebut nilainya semakin berarti dan cenderung terus naik, dan dalam waktu tidak terlalu lama diperkirakan akan dapat memasukkan dana yang jika dikurs dalam rupiah bemilai lebih dari satu trilyun. Promosi yang lebih gencar, dan kerja sama dengan biro-birowisata internasional, agaknya sangat diperlukan untuk lebih menarik wisatawan asing agar datang ke Batam.

\section{Daftar Pustaka}

Aris Ananta, "Prospects of Labor Market in Indonesia", makalah pada seminar Building on Success: Maximizing the Gains from Deregulation. Jakarta, 1995.

Asparaini Rasyad, Riau Menuju Lepas Landas, Pcmda Tingkat I Riau, Pekanbaru, 1993.

Badan Perencanaan Pembangunan Kotamadya Batam dan Kantor Statistik Batam, Perkiraan Pendapatan Regional Kotamadya Batam 19831993, Bappeko dan KS-BPS Kodya Batam, Batam, 1994.

Batam dalam Angka (berbagai tahun), Bappeko dan KS-BPS Kodya Batam, Batam, (berbagai tahun).

Pendapatan dan Pengeluaran Konsumsi Penduduk Batam 1992, Bappeko dan KS-BPS Kodya Batam, Batam, 1993.

Biro Pusat Statistik, Sensus Penduduk (berbagai tahun), Jakarta, (berbagai tahun).

BJ Habibie, Kronologis Pengembangan Daerah Industri
P. Batam, P. Rempang dan P. Galang, OPDIPB, Jakarta, 1993.

Departement of Information of the RI, Batam - The Fluorishing Island, Departement of Information, Jakarta, 1992.

Kantor Depnaker Kodya Batam, Informasi Data Ketenagakerjaan, Depnaker, Batam, 1993.

Kantor Statistik Batam dan Kantor Walikotamadya Batam, Perkembangan Ekonomi dan Kependudukan Batam, Kodya Batam dan KS-BPS Kodya Batam, Batam, (berbagai tahun).

Lemtck Universitas Indonesia, Final Report Evaluasi Master Plan Pulau Batam Lemtek UI dan PT Atelier-6, Jakarta, 1992.

Lincolin Arsyad, Ekonomi Pembangunan, Bagian Penerbitan STIE YKPN, Yogyakarta, 1992.

Kuznets, S., Modern Economic Growth, New Heaven Yale University Press, 1966.

Moh. Sukur Sakka, Batam Industrial Development Authority 22 Year, Rahmat Lestari Corp. dan BIDA. Jakarta, 1993.

Mubyarto dkk, Studi Aspek Ekonomi, Sosial Politik, dan Sosial Budaya Pengembangan Pulau Batam, Rempang dan Galang, Lembaga Penelitian UGM dan OPDIPB, Yogyakarta, 1995.

Nurimansjah Hasibuan, Pemerataan dan Pembangunan Ekonomi, Universitas Sriwijaya, Pelembang, 1993.

Otorita Pengembangan Daerah Industri Pulau Batam, Bahan Pertemuan Kasatlak Batam dengan Dewan - Pertimbangan Agung RI - Komisi Ekuin, Batam, 1995.

Pacific Economic Cooperation Council, Pacific Economic Development Report - Advancing Regional, PECC, Singapore, 1994.

R.A. Aziz, Presentasi Walikotamadya Batam tentang Penyelenggaraan Pemerintahan dan Pembangunan Kodya Batam, 1995

Sumitro Djojohadikusumo, Perkembangan Ekonomi Indonesia Sejak Pelita I, ISEI, Jakarta, 1990Pelita I, ISEI, Jakarta, 1990.

Team Survey dan Analisis Pertumbuhan Ekonomi Batam, Laporan Tahunan Perkembangan Ekonomi Batam 1993, Satlak OPDIPB dan Kantor Statistik Riau, Batam, 1994. 